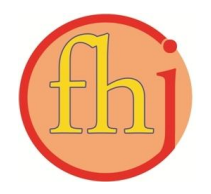

Faletehan Health Journal, 7 (1) (2020) 12-17

www. journal.Ippm-stikesfa.ac.id/ojs/index.php/FHJ

ISSN 2088-673X | e-ISSN 2597-8667

\title{
Hubungan Usia, Jenis Kelamin dan Status Anemia dengan Fungsi Kognitif pada Lanjut Usia
}

\author{
Riza Firdaus ${ }^{1 *}$ \\ ${ }^{1}$ Pasca Sarjana IImu Kesehatan M asyarakat, Universitas Sebelas M aret, Surakarta Indonesia \\ *Corresponding Author: rizafirdaus88@yahoo.co.id
}

\begin{abstract}
Abstrak
Menurunnya fungsi kognitif sangat mempengaruhi kualitas hidup lanjut usia. Faktor yang mempengaruhi adalah faktor fisiologis, psikologis dan lingkungan. Studi ini bertujuan untuk mengetahui hubungan usia, jenis kelamin dan status anemia dengan fungsi kognitif pada lanjut usia. Desain penelitian yaitu analitik observasional dengan pendekatan cross-sectional. Penelitian ini dilakukan di Panti Wredha Wening Wardoyo Semarang. Jumlah sampel yang didapatkan sebanyak 51 orang lanjut usia dengan total sampling. Variabel dependen adalah fungsi kognitif dan variabel independen adalah usia, jenis kelamin dan status anemia. Pemeriksaan fungsi kognitif diukur dengan instrumen Mini Mental State Examination (MMSE) dan pemeriksaan status anemia menggunakan haemometer dengan metode Sahli. Analisis data yang digunakan adalah menggunakan uji Chi Square. Hasil penelitian menunjukkan usia $<75$ tahun meningkatkan risiko fungsi kognitif normal $(\mathrm{OR}=6,480 ; 95 \% \mathrm{Cl} 1,844-22,769 ; \mathrm{p}=0,002)$, jenis kelamin laki - laki $(\mathrm{OR}=2,357 ; 95 \% \mathrm{Cl} 0,688-8,075 ; \mathrm{p}=0,167)$ dan anemia ringan $(\mathrm{OR}=2,821 ; 95 \% \mathrm{Cl} 0,831-9,577 ; \mathrm{p}=0,091)$. Penelitian ini menyimpulkan bahwa fungsi kognitif pada lanjut usia dipengaruhi oleh usia, jenis kelamin dan status anemia.
\end{abstract}

Kata Kunci: Anemia, Jenis Kelamin, Kognitif, Lanjut Usia, Usia

\section{Relationship of Age, Gender and Anemia Status with Cognitive Function in the Elderly}

\begin{abstract}
The decline in cognitive function greatly influences the quality of life of the elderly. Factors that influence are physiological, psychological and environmental factors. This study aims to determine the relationship of age, sex and anemia status with cognitive function in the elderly. This study was an observational analytic study with a crosssectional design. This research was conducted at Weningha Wening Wardoyo Semarang. The number of samples obtained was 51 elderly who were elected with a total sampling technique. The dependent variable was cognitive function and the independent variables were age, gender and anemia status. The examination of cognitive function was measured by the Mini-Mental State Examination (MMSE) instrument and anemia status examination using a haemometer with the Sahli method. The data analysis used was the Chi-Square test. Results: The risk of age $<75$ years increased the risk of normal cognitive function $(\mathrm{OR}=6.480 ; 95 \% \mathrm{Cl} 1.844-22,769 ; \mathrm{p}=0.002)$, male gender $(\mathrm{OR}=2.357$; $95 \% \mathrm{Cl} 0.688-8.075 ; p=0.167)$ and mild anemia $(\mathrm{OR}=2,821 ; 95 \% \mathrm{Cl} 0.831-9,577 ; \mathrm{p}=0.091)$. This study concludes that cognitive function in the elderly is influenced by age, gender and anemia status.
\end{abstract}

Keywords: Anemia, Gender, Cognitive, Elderly, Age 
Faletehan Health Journal, 7 (1) (2020) 12-17

www. journal.Ippm-stikesfa.ac.id/ojs/index.php/FHJ

ISSN 2088-673X | 2597-8667

\section{Pendahuluan}

Penurunan fungsi kognitif pada lanjut usia akan mempengaruhi kualitas hidup lansia. Gangguan kognitif adalah penurunan fungsi intelektual seperti berpikir, mengingat, bernalar dan merencanakan (Robertson, Savva, \& Anne, 2019). Lanjut usia dengan gangguan fungsi kognitif akan menyebebkan gangguan dalam melakukan aktifitas hidup sehari-hari dan menimbulkan ketergantungan dengan orang lain. Penurunan fungsi kognitif bisa terjadi seiring dengan penurunan fungsi organ tubuh sebagai akibat dari proses penuaan atau kematian sel (Purwaningsih, 2014).

Penurunan fungsi kognitif pada lanjut usia disebebkan oleh faktor fisiologis, faktor psikologis dan faktor lingkungan (Brayne \& Davis, 2012). Nutrisi atau gizi diperlukan untuk mempertahankan fungsi sel dalam menjaga kenormalan fungsi tubuh, hidup sehat, cerdas dan produktif (Hardiansyah, 2016; Undang-Undang RI, 2012). Untuk mengetahui status gizi lanjut usia perlu dilakukan suatu penilaian. Salah satunya adalah penilaian secara biokimia yaitu pemeriksaan spesimen yang diuji secara laboratorium seperti pemeriksaan kadar hemoglobin ( $\mathrm{Hb})$ (Manjilala, 2016). Kadar hemoglobin yang rendah menyebabkan anemia. Anemia pada lanjut usia menyebabkan gangguan pada fungsi fisik dan juga menyebabkan gangguang pada fungsi kognitif (Terekeci et al., 2010). Kemampuan fungsi fisik dan fungsi kognitif diperlukan dalam melakukan aktivitas hidup sehari - hari dan merupakan faktor utama yang menentukan kemandirian lanjut usia.

Badan Pusat Statistik (BPS) memproyeksikan bahwa pada tahun 2045, Indonesia akan memiliki sekitar 63,31 juta penduduk lanjut usia atau hampir mencapai 20 persen populasi, PBB juga proyeksi persentase lanjut usia Indonesia akan mencapai 25 persen pada tahun 2050 atau sekitar 74 juta lanjut usia. Selama kurun waktu hampir 50 tahun (19712018), persentase penduduk lanjut usia Indonesia meningkat sekitar dua kali lipat. Pada tahun 2018, persentase lanjut usia mencapai $9.27 \%$ atau sekitar 24,49 juta orang. Adapun persentase lanjut usia di Indonesia didominasi oleh lanjut usia muda (kelompok umur 60-69 tahun) yang persentasenya mencapai $63.39 \%$, sisanya adalah lanjut usia madya (kelompok umur 70-79 tahun) sebesar $27.92 \%$, dan lanjut usia tua (kelompok umur >80 tahun sebesar $8.69 \%$ (BPS, 2018).

Tingginya pertumbuhan penduduk lansia yang sangat pesat akan membawa dampak baik positif maupun negatif terhadap pembangunan. Dampak positif nya adalah jika lansia berada dalam keadaan mandiri, sehat, aktif, dan produktif. Di sisi lain, peningkatan jumlah lansia juga akan menjadi tantangan tersendiri ketika persiapan pra-lansia untuk menyambut masa senja tidak terlalu baik yang mengakibatkan lansia di masa mendatang jauh dari kata sehat, aktif, dan produktif. Hal tersebut berimplikasi terhadap meningkatnya beban penduduk usia produktif khususnya lansia (BPS, 2018). Bertambahnya jumlah lanjut usia diharapkan lanjut usia dapat berprestasi dimasa tua. Berprestasi adalah merupakan harapan setiap insan, baik individu itu sendiri maupun keluarga nya agar dapat mandiri dan berdaya guna sehingga tidak menjadi beban bagi dirinya sendiri, keluarga maupun masyarakat. Menurunnya kemampuan kognitif sering kali dianggap sebagai masalah biasa dan merupakan hal yang wajar terjadi pada mereka yang berusia lanjut. Padahal, menurunnya kemampuan kognitif yang ditandai dengan banyak lupa merupakan salah satu gejala awal kepikunan yang tentunya sangat mempengaruhi kualitas hidup lanjut usia.

Berdasarkan studi pendahuluan yang peneliti lakukan di Panti Wredha Wening Wardoyo, didapatkan data terdapat 91 orang lanjut usia. Dari 91 orang lanjut usia tersebut didapat data 38 orang lanjut usia sering mengeluh pusing, 10 orang lanjut usia mengeluh badan terasa lemah, 2 orang mengeluh sering mual. Berdasarkan observasi langsung yang peneliti lakukan pada 7 orang lanjut usia didapatkan data 4 orang lanjut usia mempunyai konjungtiva agak anemis, mengeluh lemah letih lesu, dan nafsu makan kurang, tubuh tampak kurus dan terkadang mengeluh sakit kepala, dan mengatakan sering lupa, dan 1 orang lanjut usia mengalami depresi ringan. Berdasarkan data di atas, peneliti tertarik untuk meneliti dan mengetahui hubungan usia, jenis kelamin dan status anemia terhadap fungsi kognitif pada lanjut usia di Panti Wredha Wening Wardoyo Semarang.

\section{Metode Penelitian}

Desain penelitian ini menggunakan desain penelitian analitik observasional dengan desain 
Cross sectional, dimana status paparan dan penyakit diukur pada saat yang sama (Murti, 2016). Populasi umum dalam penelitian ini adalah semua lanjut usia yang ada di Panti Wredha Wening Wardoyo yang berjumlah 91 orang dan yang menjadi sampel adalah para lanjut usia berusia $\geq 60$ tahun yang ada di Panti Wreda Wening Wardoyo Semarang yang memenuhi kriteria inklusi yaitu kriteria pengambilan sampel yang ditentukan oleh peneliti (UMSL, 2017), seperti lanjut usia yang bisa diajak komunikasi, bisa mendengar dengan baik, bersedia menjadi responden, tidak mengalami gangguan jiwa dan tidak ketergantungan fisik berat.

Jumlah sampel yang memenuhi kriteria inklusi adalah sebanyak 51 oarang responden. Teknik pengambilan sampel. yang digunakan dalam pengambilan sampel adalah total sampling. Variabel dependen dalam penelitian ini adalah fungsi kognitif dan variabel Independennya adalah usia, jenis kelamin dan status anemia. Metode pengukuran yang digunakan dalam pemeriksaan fungsi kognitif adalah diukur dengan instrumen Mini Mental State Examination (MMSE) yang merupakan suatu tes skrining yang cukup valid dalam pemeriksaan gangguan kognisi. MMSE adalah salah satu pemeriksaan status mental yang paling banyak digunakan Folstein, Folstein and McHugh (1975) Tes ini terdiri atas dua bagian yaitu: pemeriksaan respons vokal yang meliputi pemeriksaan orientasi, memori dan atensi dan memeriksa kemampuan dalam menyebutkan nama, mengikuti perintah verbal dan tulisan, menuliskan kalimat dan mengkopi gambar (Tjokronegoro, 2001). Pemeriksaan status anemia menggunakan haemometer dengan metode Sahli. Menurut Kementerian Kesehatan RI, (2010, 2015) Alat pemeriksaan kadar Hemoglobin yang bisa digunakan adalah hemoglobinometer sahli $(\mathrm{Hb}$ Sahli); hemoglobinometer POCT; fotometer; atau hematologi analizer. Peneliti ini menggunakan metode Sahli dikarenakan alat tersebut mudah didapatkan, mudah digunakan, bisa dibawa kemana - mana, dan biaya operasional lebih murah dibandingkan dengan penggunaan metode yang mempergunakan alat spektrofotometer, hematologi analizer, walaupun tingkat kesalahan 2 - 3 kali kesalahan rata - rata dari metode yang menggunakan spektrofotometer (Nyoman, 2001). Model dan metode analisis data yang digunakan adalah Uji Chi -Square. Etika penelitian dalam penelitian ini meliputi persetujuan penelitian (informed cosent), tanpa nama (anonymity) dan kerahasiaan (confidentiality).

\section{Hasil}

Karakteristik responden dalam penelitian ini terdiri dari, usia dan jenis kelamin. Di dalam penelitian ini dari 51 responden didapatkan bahwa usia yang terbanyak adalah berusia $<75$ tahun yaitu sebanyak 28 orang $(54.9 \%)$ hal ini juga sesuai dengan data lanjut usia yang ada di panti, Wredha Wening Wardoyo yang terbanyak adalah usia antara $60-74$ tahun. Usia tersebut termasuk dalam katagori lanjut usia (elderly) (BPS, 2018).

Tabel 1. Karakteristik Sampel

\begin{tabular}{lcc}
\hline \multicolumn{1}{c}{ Variabel } & n & \% \\
\hline Usia & & \\
$<75$ tahun & 28 & 54,9 \\
$\geq 75$ tahun & 23 & 45,1 \\
\hline Jenis Kelamin & & \\
Laki-laki & 15 & 29,4 \\
$\quad$ Perempuan & 36 & 70,6 \\
\hline Jumlah & 51 & 100 \\
\hline
\end{tabular}

Tabel 2. Distribusi Silang Variabel Independen dan Dependen

\begin{tabular}{lcc}
\hline \multirow{2}{*}{ Variabel } & \multicolumn{2}{c}{ Fungsi Kognitif } \\
\cline { 2 - 3 } & Normal & Terganggu \\
\cline { 2 - 3 } & $\%$ & $\%$ \\
\hline Usia & 35,3 & 19,6 \\
$\quad<75$ tahun & 9,8 & 35,3 \\
$\quad \geq 75$ tahun & & \\
\hline Jenis Kelamin & 17,6 & 11,8 \\
$\quad$ Laki-laki & 27,5 & 43,1 \\
$\quad$ Perempuan & & \\
Status Anemia & 19,6 & 11,8 \\
$\quad$ Ringan & 25,5 & 43,1 \\
$\quad$ Sedang/Berat & $\mathbf{1 0 0}$ & $\mathbf{1 0 0}$ \\
\hline Total & & \\
\hline
\end{tabular}

Tabel 3. Distribusi Nilai Chi-Square

\begin{tabular}{lccc}
\hline \multicolumn{1}{c}{ Variabel } & Value & df & $\begin{array}{c}\text { Asymp.Sig } \\
(2 \text {-sides) }\end{array}$ \\
\hline Usia & 9,232 & 1 & 0,002 \\
Jenis Kelamin & 1,906 & 1 & 0,167 \\
Status Anemia & 2,851 & 1 & 0,91 \\
\hline
\end{tabular}


Faletehan Health Journal, 7 (1) (2020) 12-17

www. journal.Ippm-stikesfa.ac.id/ojs/index.php/FHJ

ISSN 2088-673X | 2597-8667

Data jenis kelamin menunjukkan sebanyak 15 orang $(29.4 \%)$ berjenis kelamin laki - laki dan 36 orang $(70.6 \%)$ berjenis kelamin perempuan, sehingga dapat dikatakan bahawa responden yang berjenis kelamin perempuan lebih banyak dari pada yang berjenis kelamin laki - laki, sesuai dengan data statistik persentase penduduk lanjut usia menurut kelompok umur tahun 2018 yaitu laki - laki $8.78 \%$ dan perempuan $9.77 \%$ (BPS, 2018).

Dari tabel 2 dapat diketahui bahwa responden yang berusia $<75$ tahun $35.3 \%$ mempunyai fungsi kognitif normal dan $19.6 \%$ mempunyai fungsi kognitif terganggu, sedangkan responden berusia $>75$ tahun dengan fungsi kognitif normal sebanyak $9.8 \%$ dan $35.3 \%$ dengan fungsi kognitif terganggu. Responden yang berjenis kelamin laki - laki sebanyak $17.6 \%$ mempunyai fungsi kognitif normal dan $11.8 \%$ mempunyai fungsi kognitif terganggu sedangkan responden perempuan 27.5\% mempunyai fungsi kognitif normal dan 43.1\% mempunyai fungsi kognitif terganggu. Responden yang menderita anemia ringan dengan fungsi kognitif normal sebanyak $19.6 \%$ dan dengan fungsi kognitif terganggu $11.8 \%$ sedangkan responden yang menderita anemia sedang / berat dengan fungsi kognitif normal $25.5 \%$ dan dengan fungsi kognitif terganggu sebanyak $43.1 \%$.

Dari hasil uji Chi-Square test pada tabel 3 dapat diketahui bahwa variabel usia didapatkan nilai $\mathrm{x}^{2}$ hitung : $9.232 \geq \mathrm{x}^{2}$ tabel : 3.841 dan nilai $\mathrm{p}$ $=0.002<0.05$, variabel jenis kelamin didapatkan nilai $\mathrm{x} 2$ hitung : $1.906 \leq \mathrm{x} 2$ tabel : 3.841 dan nilai $\mathrm{p}=0.167>0.05$ dan variabel status anemia didapatkan nilai $\mathrm{x}^{2}$ hitung : $2.851^{\mathrm{a}} \geq \mathrm{x}^{2}$ tabel : 3.841 dan nilai $\mathrm{p}=0.091>0.05$ dapat disimpulkan hubungan usia dengan fungsi kognitif signifikan, sedangkan jenis kelamin dan status anemia dengan fungsi kognitif kurang signifikan.

Pada tabel 4, dapat diketahui terdapat hubungan antara usia $<75$ tahun dengan fungsi kognitif dan secara statistik signifikan. Lanjut usia $<75$ tahun kecenderungan mempunyai fungsi kognitif normal 6.4 kali dibandingkan dengan usia $\geq 75$ tahun $(\mathrm{OR}=6.48 ; 95 \% \mathrm{CI}=1.84-22.76$; $\mathrm{p}=0.002$ ), hubungan antara jenis kelamin dengan fungsi kognitif dan secara statistik tidak signifikan. Lanjut usia yang berjenis kelamin laki - laki cenderungan mempunyai fungsi kognitif normal 2.3 kali dibandingkan dengan lanjut usia yang berjenis kelamin perempuan $(\mathrm{OR}=2.35$; $95 \% \mathrm{CI}=0.68-8.07 ; \mathrm{p}=0.167)$ dan hubungan antara status anemia dengan fungsi kognitif dan secara statistik tidak signifikan. Lanjut usia dengan anemia ringan cenderungan mempunyai fungsi kognitif normal 2.8 kali dibandingkan dengan lanjut usia dengan anemia sedang / berat $(\mathrm{OR}=2.35 ; 95 \% \mathrm{CI}=0.68-8.07 ; \mathrm{p}=0.091)$.

\section{Pembahasan}

Hubungan antara usia dengan fungsi kognitif pada lanjut usia. Proses menua tidak terlepas dari teori tentang sel, penuaan atau kematian sel berhubungan dengan struktur nukleotida di ujung kromosom di dalam inti sel eukariot yang disebut telomer. Pada sel somatik normal terjadi pemendekan telomer seiring meningkatnya usia, termasuk stem cell yang dimaksudkan untuk pembaharuan sel (Purwaningsih, 2014). Kematian sel pada organ tubuh seiring dengan peningkatan usia akan mempengaruhi fungsi organ.

Tabel 4. Risk Estimate

\begin{tabular}{lcccc}
\hline \multicolumn{1}{c}{ Variabel } & Value & \multicolumn{2}{c}{$\mathbf{9 5 \%}$ Confidence Interval } & p \\
\cline { 3 - 4 } & OR & Lower & Upper & \\
\hline $\begin{array}{l}\text { Usia } \\
(<75 \text { tahun / }>75 \text { tahun })\end{array}$ & 6.480 & 1.844 & 22.769 & 0.002 \\
$\begin{array}{l}\text { Jenis Kelamin } \\
\text { (Laki-laki / Perempuan) }\end{array}$ & 2.357 & 0.688 & 8.075 & 0.167 \\
$\begin{array}{l}\text { Anemia } \\
\text { (Ringan / Sedang Berat) }\end{array}$ & 2.821 & 0.831 & 9.577 & 0.91 \\
\hline
\end{tabular}


Hasil dari penelitian yang dilakukan oleh Robertson, Savva and Anne (2019) bahwa kelemahan fisik dan fungsi kognitif adalah saling berkaitan. Fungsi kognitif dan kelemahan berinteraksi dalam siklus penurunan yang terkait dengan penuaan. Kesehatan otak sangat terkait dengan kesehatan fisik, dan psikis. Penelitian Robertson, Savva and Anne (2019) juga sesuai dengan penelitian yang dilakukan oleh Gillis et al. (2019), bahwa penurunan fungsi kognitif akan terjadi seiring dengan peningkatan usia. Hasil dari kedua penelitian diatas sesuai dengan penelitian ini bahwa terdapat hubungan yang signifikan antara usia dengan fungsi kognitif pada lanjut usia, dapat di simpulkan bahwa penurunan fungsi organ atau kerusakan fungsi organ akibat proses penuaan mempengaruhi fungsi kognitif pada lanjut usia. Semakin bertambahnya usia secara bertahap menurunkan fungsi kognitif.

Hubungan antara jenis kelamin dengan fungsi kognitif pada lanjut usia. Hasil dari penelitian ini didapatkan jumlah yang terbanyak adalah responden perempuan yaitu $70.6 \%$ lebih banyak dari pada responden laki-laki dan begitu juga fungsi kognitif yang terganggu juga terbanyak dialami oleh responden perempuan yaitu sebesar $43.1 \%$. Hal ini terjadi karena jumlah lanjut usia perempuan di Indonesia lebih banyak dari lanjut usia laki - laki yaitu sebesar 52.43\% (BPS, 2018). Dari data diatas dapat dilihat peluang terbesar untuk terjadinya gangguan fungsi kognitif yang terbanyak akan dialami oleh lanjut usia perempuan.

Dari penelitian yang dilakukan oleh Rasyid, Syafrita and Sastri (2017) bahwa tidak terdapat hubungan jenis kelamin dengan fungsi kognitif pada lanjut usia di Kecamatan Padang Panjang Timur Kota Padang Panjang. Penelitian Rasyid, Syafrita and Sastri (2017) selaras dengan hasil penelitian ini yaitu tidak terdapat hubungan yang signifikan antara jenis kelamin dengan fungsi kognitif pada lanjut usia. Hasil penelitian ini berbeda dengan penelitian yang dilakukan oleh Muller-Gerards et al., (2019) bahwa peluang untuk kejadian gangguan fungsi kognitif ringan pada laki - laki paling tinggi. Dari perbedaan pendapat ini perlu dilakukan penelitian lebih lanjut dan dengan sampel yang lebih besar terkait dengan faktor fisik, psikis dan lingkungan yang mempengaruhi fungsi kognitif pada lanjut usia.
Hubungan status anemia dengan fungsi kognitif pada lanjut usia. Gangguan kognitif adalah penurunan fungsi intelektual seperti berpikir, mengingat, bernalar dan merencanakan (Robertson et al., 2019).Terganggunya fungsi kognitif pada lanjut usia bisa disebabkan oleh beberapa faktor : faktor fisiologis seperti penyakit serebral primer, Alzeimer, patologi serebrovaskular dan penyakit ekstrakranial dan banyak lagi yang tidak diketahui penyebabnya (Brayne \& Davis, 2012). Faktor psikologis seperti: stres emosional berat, depresi, ansietas, mania, paranoid, berduka, defisit sensori persepsi, dan faktor lingkungan seperti: lingkungan yang tidak dikenal, deprivasi sensori lingkungan yang membosankan sehingga menimbulkan berkurangnya arti lingkungan, sensori yang berlebihan, dan immobilisasi terapeutik. Defisiensi vitamin B (5-20\% dari populasi lansia) berkontribusi pada gangguan kognitif (Gómez, Francisco, Sevilla, Mu, \& Bergman, 2017).

Faktor yang mempengaruhi lanjut usia mengalami gangguan fungsi kognitif adalah adanya gangguan suplai oksigen, glukosa, dan zat gizi dasar, defisiensi vitamin (terutama tiamin), malnutrisi dan lain-lain (Wiscarz, 1998). Secara alamiah pada lanjut usia mulai mengalami perubahan fungsional pada tubuhnya. Hasil penelitian yang dilakukan oleh peneliti menunjukkan tidak terdapat hubungan yang signifikan antara status anemia dengan fungsi kognitif pada lanjut usia. Anemia adalah suatu kondisi di mana jumlah sel darah merah tidak mencukupi untuk memenuhi kebutuhan fisiologis tubuh (WHO, 2011).

\section{Simpulan}

Penelitian ini menyimpulkan bahwa anemia bukan satu - satunya faktor yang mempengaruhi fungsi kognitif pada lanjut usia, faktor lain yang mempengaruhi fungsi kognitif pada lanjut usia seperti faktor psikologis dan faktor lingkungan tetapi anemia dapat meningkatkan kecenderungan untuk terganggunya fungsi kognitif pada lansia.

\section{Referensi}

BPS. (2018). Statistik Penduduk Lanjut Usia 2018. Badan Pusat Statistik.

Brayne, C., \& Davis, D. (2012). Making Alzheimer's and dementia research fit for populations. Lancet, 380(pp.141). 
Faletehan Health Journal, 7 (1) (2020) 12-17

www. journal.Ippm-stikesfa.ac.id/ojs/index.php/FHJ

ISSN 2088-673X | 2597-8667

Folstein, M. F., Folstein, S. E., \& McHugh, P. R. (1975). A practical method for grading the cognitive state of patients for the clinician, Res.1975(12), 189-198.

Gillis, C., Mirzaei, F., Potashman, M., Maserejian, N., \& Ikram, M. (2019). The incidence of mild cognitive impairment: A systematic review and data synthesis, (May), 2019. https://doi.org/10.1016/j.dadm.2019.01.004

Gómez, S., Francisco, Á., Sevilla, R., Mu, M., \& Bergman, I. (2017). Anaemia in the elderly ¿. 149(11), 496-503. https://doi.org/10.1016/j.medcle.2017.10.02 7

Hardiansyah. (2016). Sejarah dan Masa Depan Ilmu Gizi. Ilmu Gizi Teori dan Aplikasi. Jakart: EGC.

Kementerian Kesehatan RI. (2010). Peraturan Menteri Kesehatan republik Indonesia Nomor 1464 / Menkes /Per / X / 2010 Tentang Ijin dan Penyelenggaraan Praktik Bidan. Jakarta.

Kementerian Kesehatan RI. (2015). Peraturan Menteri Kesehatan RI Nomor 25 Tahun 2015 tentang Penyelenggaraan Pemeriksaan Laboratorium Untuk Ibu Hamil, dan Nifas di Fasilitas Pelayanan Kesehatan dan Jaringan Pelayanannya. Jakarta.

Manjilala. (2016). Penilaian Status Gizi Secara Biokimia. Ilmu Gizi Teori dan Aplikasi. Jakarta: EGC.

Muller-Gerards, D., Weimar, C., Abramowski, J., Tebrugge, S., \& Jokisch, M. (2019). Subjective cognitive decline, APOE $\varepsilon 4$, and incident mild cognitive impairment in men and women, 11(May), 221-2302019. https://doi.org/10.1016/j.dadm.2019.01.007

Murti, B. (2016). Prinsip dan Metodologi Riset Epidemiologi (Empat). Surakarta: Program Studi Ilmu Kesehatan Masyarakat, Program Pascasarjana, Universitas Sebelas Maret.

Nyoman, S. (2001). Penilaian Status Gizi,Jakarta. EGC.
Purwaningsih, E. (2014). Pemendekan Telomer Dan Apoptosis Telomere Shorthening And Apoptosis. KEDOKTERAN YARSI, 22(2), 132-141. Retrieved from https://media.neliti.com

Rasyid, I. Al, Syafrita, Y., \& Sastri, S. (2017). Artikel Penelitian Hubungan Faktor Risiko dengan Fungsi Kognitif pada Lanjut Usia Kecamatan Padang Panjang Timur Kota Padang Panjang. Andalas Journal of Health, $6(1), \quad 49-54 . \quad$ Retrieved from http://jurnal.fk.unand.ac.id

Robertson, D. A., Savva, G. M., \& Anne, R. (2019). Frailty and cognitive impairment A review of the evidence and causal mechanisms. Ageing Research Reviews, 12(4), 840-851. https://doi.org/10.1016/j.arr.2013.06.004

Terekeci, H. M., Kucukardali, Y., Onem, Y., Akyol, A., Kucukardali, B., Sahan, B., ... Oktenli, C. (2010). European Journal of Internal Medicine Relationship between anaemia and cognitive functions in elderly people. European Journal of Internal Medicine, 21(2), 87-90. https://doi.org/10.1016/j.ejim.2009.12.005

Tjokronegoro, A. (2001). Buku Ajar Ilmu Penyakit Dalam.Jilid II. Jakarta: Balai Penerbit FKUI.

UMSL. (2017). Populations and sampling. Retrieved from https://www.umsl.edu/ lindquists/sample.ht $\mathrm{ml}$

Undang-Undang RI. (2012). Undang - Undang Republik Indonesia Nomor 18 tahun 2012 Tentang Pangan. Jakarta. Jakarta.

WHO. (2011). Haemoglobin concentrations for the diagnosis of anaemia and assessment of severity, 1-6. Retrieved from https://www.who.int/vmnis/indicators/haem oglobin.pdf

Wiscarz, G. (1998). Buku Saku Keperawatan Jiwa. Edisi ke-3. Jakarta: EGC. 